\title{
A QUANTITATIVE EVALUATION OF THEORETICAL RENEWABLE ENERGY POTENTIAL OF THE BUILDING SITE
}

\author{
Vygantas ŽĖKAS ${ }^{\mathrm{a}}$, Vytautas MARTINAITIS ${ }^{\mathrm{a}}$, Giedre STRECKIENÉ ${ }^{\mathrm{a}}$, Tatjana VILUTIENE் ${ }^{\mathrm{b}}$ \\ ${ }^{a}$ Department of Buildings Energetics, Vilnius Gediminas Technical University, \\ Saulètekio al. 11, 10223 Vilnius, Lithuania \\ ${ }^{b}$ Department of Construction Technology and Management, Vilnius Gediminas Technical University, \\ Saulètekio al. 11, 10223 Vilnius, Lithuania
}

Received 03 Sep 2014; accepted 30 Sep 2014

\begin{abstract}
Modern building design process is becoming more complex. Local conditions and future constructions are computer-simulated. The aim of this simulation is to evaluate theoretical RE potential for the successful and efficient exploitation of the new building. As usual, in the simulation process of local conditions, the assessment of the renewable energy potential is one of the key elements. This article presents and analyses the idea of the quantitative evaluation of renewable energy (RE) theoretical potential of the building site and the approach on how to prepare initial data file for further process of site energy development concept creation. The study describes a building site that is undergoing the RE evaluation in terms of thermodynamic and descriptive statistics characteristics. The applicability of the offered approach was verified in the case study. The specified evaluation of the combined energy fluctuation throughout the year provides new and potentially crucial information about the issues of the RE hybrid energy transformation systems' modelling and about the efficient use of resources to ensure the same level of energy services.
\end{abstract}

Keywords: building site, energy efficiency, disposable renewable energy, theoretical potential.

\section{Introduction}

The Directive on the promotion of the use of energy from renewable sources (Directive 2009/28/EC 2009) sets the objective of reaching $20 \%$ of the EU's energy consumption through renewable energy sources by 2020 . On $18^{\text {th }}$ June 2010, the recast of Directive 2010/31/EU on the Energy Performance of Buildings (EPBD) was published amending Directive 2002/91/EC (2003). The recast introduces a European-wide definition of "nearly zero energy buildings" and indicates that the new buildings will have to be nearly zero energy buildings by $31^{\text {st }}$ December 2020 with public buildings having to fulfil this standard two years earlier. Nearly zero energy buildings are now defined in the EPBD (2010) as constructions that have "a very high energy performance". This definition requires both a decreased energy use in buildings whilst also bringing about a renewable energy requirement: "The nearly zero or very low amount of energy required should to a very significant extent be covered by energy from renewable source, including renewable energy produced on-site or nearby" (Directive 2010/31/EU, EPBD 2010). Directive encourages architects and planners to properly consider the optimal combination of improvements in energy efficiency and use of energy from renewable sources when planning, designing, building and renovating industrial or residential areas.

In the processes of building design, operation and maintenance, the technological, institutional and cultural cooperation of architects, engineers and constructors (AEC) is very important. From an energy engineering point of view, the development of decentralised energy generation and use should be planned by coordinating quantitative and qualitative indicators of renewable energy (RE) and decentralised generators in the intended construction or an existing building.

The vision of sustainable building was discussed in the last decade (Adeli 2002; Ali, Armstrong 2008; Wang, Adeli 2013; Kaczorek, Koczyk, 2013; Parasonis et al. 2012; Džiugaitė-Tumènienè et al. 2012; Brauers et al. 2012) pointing that a successful creation of sustainable infrastructure systems and environmentally-conscious designs requires a holistic, integrated, and multidisciplinary approach. Unfortunately, because of the large number and diversity of participants, construction work is characterised by a fragmented decision-making process, fear of venture, and conservatism, which result in innovation avoidance and missed opportunities (Altwies, Nemet 2013). However, these problems are being addressed and building creation tools are being developed. One example is the traditional concept of the construction process based on the Integrated Whole Building Design (IWBD) (Integrated Whole Building Design Guidelines) (Ministry for the Environment Wellington 2008), which is now widely referred to as Integrated Project Delivery (IPD) (AIA 2013), together with lifespan analysis of the building and its engineering systems. Moreover, through a digital building concept (Watson 2011), ICT offers va- 
rious tools for the construction process, from CAD engineering, first introduced approximately two decades ago, to the more recent BIM (Umit 2012; Barlish, Sullivan 2012). The integration of IPD and BIM is becoming more popular, and the problems involved in this process are being identified and solved (Cholakis 2011; Xie et al. 2011; Wright, Charalambides 2011; Azari-Najafabadi et al. 2011; Sebastian 2010; Popov et al. 2010; Migilinskas et al. 2013; Lin 2014; Volk et al. 2014; Barlish, Sullivan 2012).

In this IPD and BIM development situation, the concepts corresponding to a coordinated integration of $\mathrm{RE}$, particularly in the technological, institutional and cultural development path through AEC collaboration, are required. Therefore, engineering is needed to provide quality assistance in the initial design stage when developing the concept of a building.

To obtain an efficient integration of RE usage, it is necessary to evaluate its potential at the first ("predesign") stage, i.e., at the stage of building concept creation. At this stage, the technical conditions of the site should be determined, the synthesis and conflicts of the energy needs and the local conditions generated, and the initial concept development created. The locally available energy should be used to guide the selection of the planned activities. Such guidance facilitates the development of a responsible user, and the distributed energy generation achieved by implementing IWBD process with BIM ensures that the user's needs are met, which allows, even in the operation and maintenance phase, for the optimal management/improvement of the building.

To prepare information on the required area that reflects the potential RE sources, it is necessary to identify the types of RE sources and evaluate their quantities and qualities. For decision making, this combined information is a crucial one. To determine RE availability, various tools and methods are applied (Angelis-Dimakis et al. 2011). The main evaluation principle is that the determined potential can be of three levels: the theoretical potential, the technical potential and the exploitable potential. To obtain theoretical RE potential, as a first stage of assessment a quantitative (energy) (Liao et al. 2012; Jorgensen, Svirezhnev 2004) and qualitative (exergetic) (Wall, Gong 2001; Hermann 2006; Valero et al. 2010; Beyene et al. 2012; Shukuya, Komuro 1996) resource evaluation is performed as well as statistical data are processed. Statistical data processing can be performed in the initial meteorological data generating stage, as well as in the stage of recalculating them into the quantitative/qualitative indicators. As shown by some of the most recent examples (Demirhan et al. 2013; Muratori et al. 2013) the statistics methods are widely applied. The statistical analysis provides additional characteristics that enable to evaluate inconsistency in terms of RE flow variation in time.

Developers having information on possible renewable energy sources of available building sites could select most appropriate from the alternatives that are consistent with the development concept.
In the combined evaluation of the energy potential, the review (Angelis-Dimakis et al. 2011) sets methods to evaluate the types of RE that should be integrated with each other and presented at the same level of particularity. In order to not restrict the way of choosing technological solution, it is obligatory to have RE potential data which has to be in uniform detail and affected by local conditions.

With the development of technology and the expansion of data sharing and storage area network, the databases which can be accessed remotely were created with meteorological data as a primary information about RE for many places of the world (Sorrentino et al. 2012). Approximate meteorological data could be obtained using widely applied interpolation method of any spot of the world (Meteotest 2013). Evaluating the potential of the $\mathrm{RE}$, its layoutin the territory, GIS is widely known and applied (Van Hoesen, Letendre 2010; Ondreka et al. 2007; Omitaomu et al. 2012). The particularity of information used in the maps is applied to the cities or regions for the use of RE potential planning. It presents average values of the available potential of $\mathrm{RE}$ for the particular area or zone. In addition to the technical data provided by this method, optimization methods are used (Omitaomu et al. 2012; Malczewski 2006; Monstvilas et al. 2012) which allow to plan the new areas and the volumes for RE projects more objectively and efficiently.

The review shows that in the modelling of buildings as individual energy users there is a lack of unified approach to the assessment of the potential RE in the building site and site initial RE potential information that would allow to choose in uniform level of detail the most acceptable source of energy or to adopt primary technology solutions. An engineer should have the initial data file from which he could retrieve initial appropriate conceptual engineering solutions for further modelling. This article presents method based on thermodynamic analysis for determining the theoretical potential of RE of the building site and statistical evaluation of disposable RE flows. In this way, the initial data file of the building site RE potential is formed so that it could be used for further modelling of site development concept.

Conceptual framework of main energy efficient building planning and design stages is presented in Figure 1. In this paper the analysis is performed on the stage 1 (building site data analysis and limitations) of energy efficient building planning and design process. Detailed description of the first stage approach is presented in Figure 2. This paper is focusing on renewable energy (RE) theoretical potential of the building site only. In future the authors plan to assess technical potential of building site by analysing RES technologies and energy use profile. Separate conceptual building sustainability solutions on different stages of research were discussed earlier (Motuzienè et al. 2013; Lapinskiené, Martinaitis 2013; Motuzienè, Vilutienè 2013; Mikučionienè et al. 2014; Žèkas et al. 2013; Motuzienè, Bielskus 2014; Lapinskienè et al. 2014). 


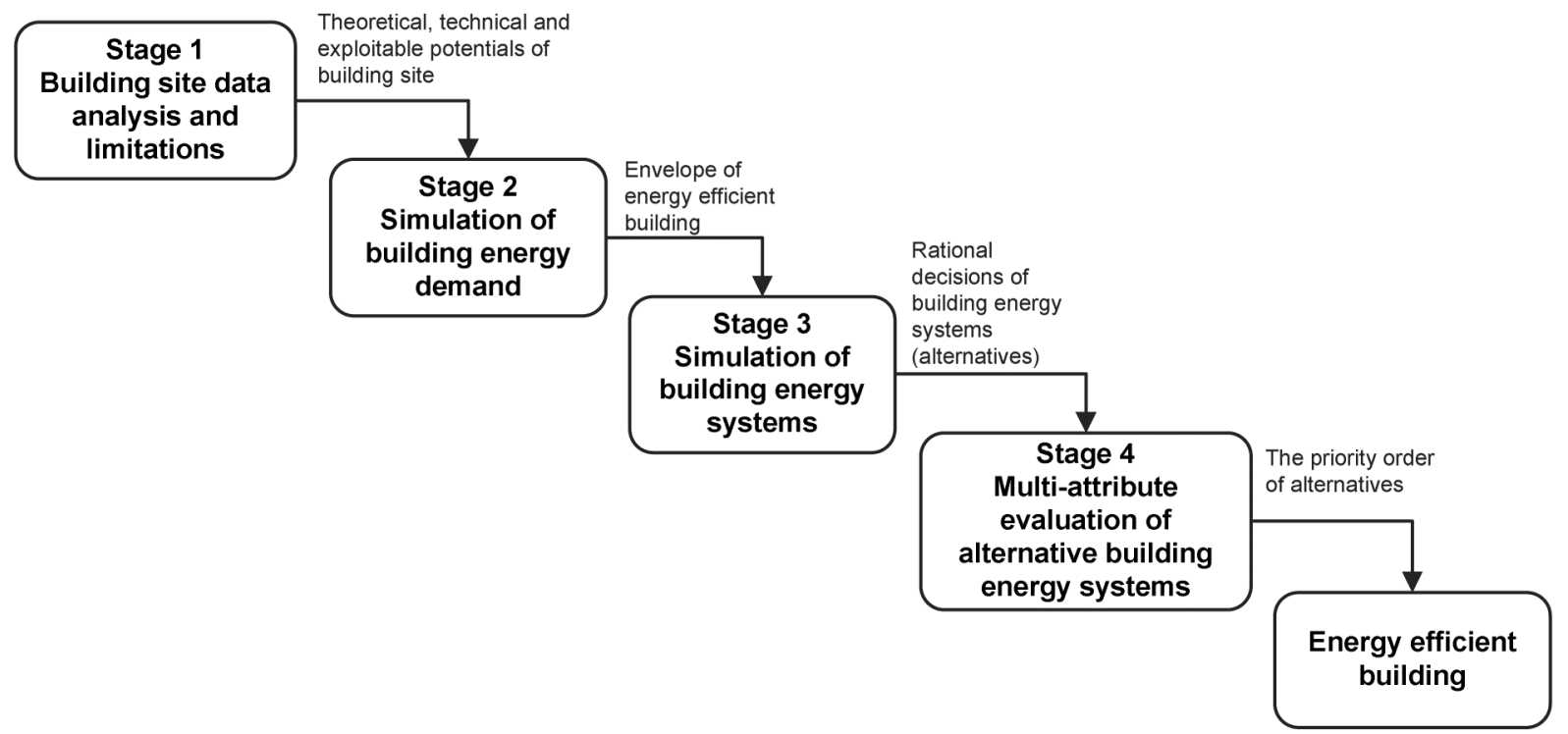

Fig. 1. Conceptual framework of main energy efficient building planning and design stages

\section{Stage 1 \\ Building site data analysis and limitations}

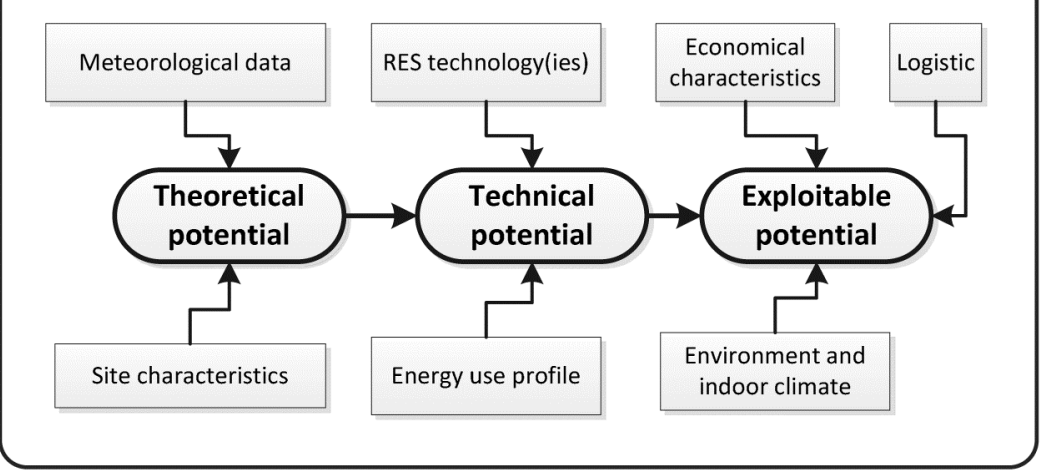

Fig. 2. Detailed description of the first stage approach

\section{A conceptual combined evaluation method of RE of the building site}

In order to ensure a consistent and uniform level of detail of analysed site RE information, it is offered to assess theoretical RE potential by following the approach that is presented in the Figure 3. First, third, fourth and fifth blocks marked in red show the scope of research presented in paper. Second block shows the initial data necessary for simulation. Fourth block of research is based on application of renewable energy flows assessment methods described in Section 2.4. The application for RE flows calculator used on this stage is based on aforementioned energy flows assessment methods and is written in $\mathrm{C}++$ language. The application reads meteorological data and calculates energy flows and visualizes it using interactive plots. To develop graphical user interface applications the Qt cross platform application framework is used. For plotting and data visualization the QcustomPlot (2013) library is used. Application helps analyse data quickly and interactively. Approach gives a unified way to assess site's RE potential and the possibility to assess objective- ly the particular site not only when developing opportunities, but also considering different site alternatives.

\subsection{Control volume of the building site}

For a building as single energy user with existing RE flows, it is possible to adapt the principle of energy analysis and evaluate a defined open space streaming process system, which deposits some of the energy flow formed from the RE sources. In order to unify the site RE potential integrated evaluation method, the site in terms of thermodynamic analysis is considered to be volume, defined by control volume boundaries (Fig. 4). Notations of Figure 4(a) represent three incoming (the solar radiation heat flow $\dot{Q}_{S}^{+}$; the ground heat flow $\dot{Q}_{G}^{+}$; and the incoming air flow transformation energy $\dot{W}_{A}^{+}$) and two outgoing energy flows (the outgoing air transformation energy $\dot{W}_{A}^{-}$and the radiation heat $\dot{Q}^{-}$).

The structure and development of available RE in a building site throughout the year is a fundamental factor 


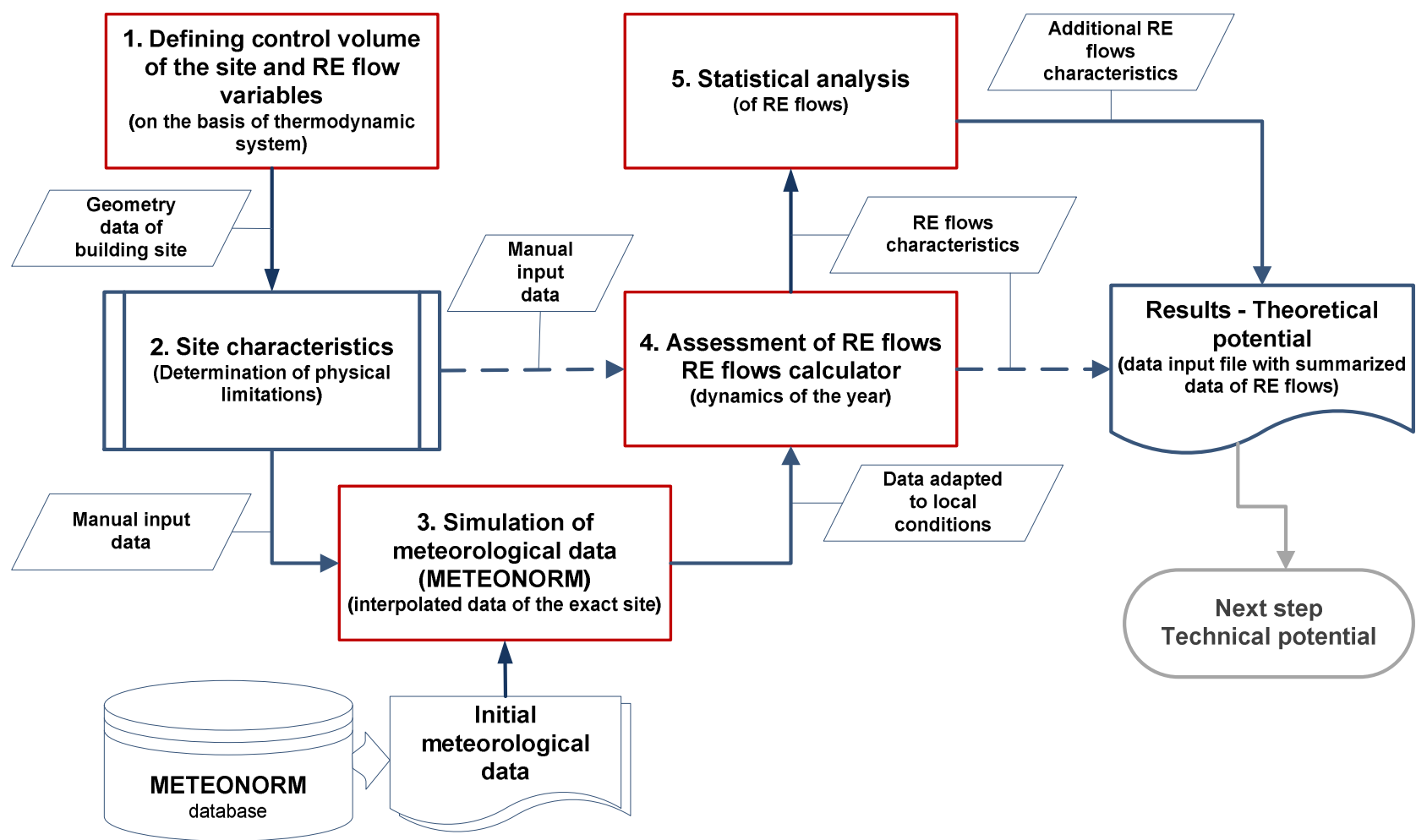

Fig. 3. Algorithm of theoretical RE potential assessment for building site

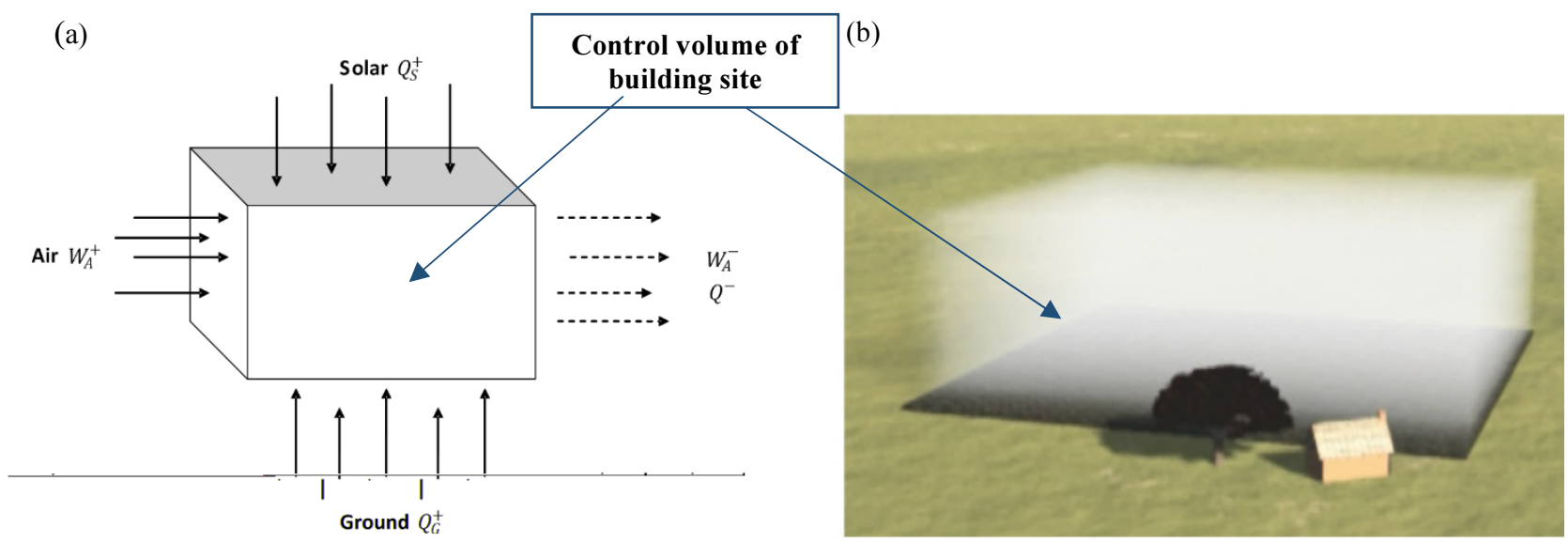

Fig. 4. The energy flows crossing the control volume: (a) RE flow variables, (b) visualization of control volume of the building site

in decision making regarding the usage of RE technologies in buildings. It is assumed that to increase RE integrity and effectiveness, it is necessary to determine the local RE potential that would enable to identify both separate flows as well as technical parameters of complex flow.

\subsection{Site characteristics}

RE potential and its dynamics in the year period, influenced by surrounding factors, is a primary and one of the main theoretical RE potential evaluation tasks. This task involves the description of site's physical characteristics. Summarized site's physical characteristics' data file structure is presented in the Figure 5 scheme.

When physical characteristics of the building site are structured and prepared, a meteorological data file should be prepared, following influences of physical characteristics. In this way it could be possible to have sufficient detailed input data of a particular site to evaluate RE theoretical potential.

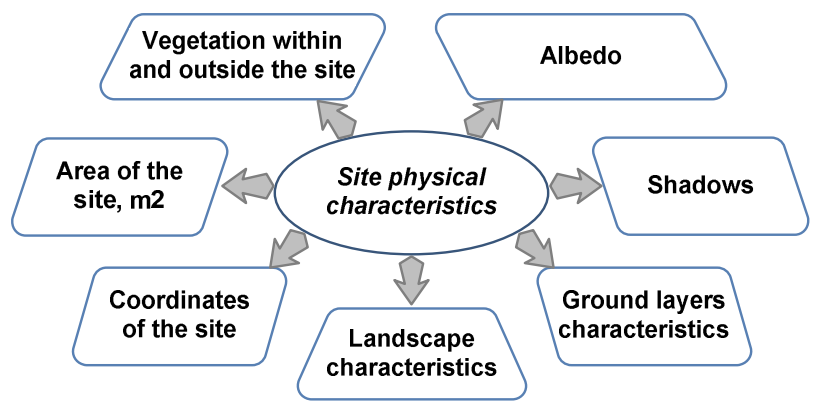

Fig. 5. Structure of building site's physical characteristics 


\subsection{Meteorological data}

Taking into account the structure of building site's physical characteristics the meteorological data should be adapted to the local conditions. METEONORM application has been chosen for meteorological data processing. Initial meteorological data is taken from METEONORM meteorological data base. When forming meteorological data array of a particular site, the following provisions are applied:

1. Central geographical point of the site is picked as a point presenting all site's meteorological phenomena.

2. RE theoretical potential evaluation is performed using historical data of long-term observations and the program generates the typical meteorological year.

3. Meteorological data is provided by hourly time interval.

\subsection{Assessment of renewable energy flows}

The concept of complex RE assessment is that the control volume limits are crossed by three incoming (the solar radiation heat flow $\dot{Q}_{S}^{+}$; the ground heat flow $\dot{Q}_{G}^{+}$; and the incoming air flow transformation energy $\dot{W}_{A}^{+}$) and two outgoing energy flows (the outgoing air transformation energy $\dot{W}_{A}^{-}$and the radiation heat $\dot{Q}^{-}$), which are shown in the Figure 4.

The energy balance for this system of constant volume with a stationary streaming process can be modelled by the Eqn (1):

$$
\Sigma_{i}\left[\dot{Q}_{i}^{+,-}\right]+\Sigma_{j}\left[\dot{W}_{j}^{+,-}\right]=\frac{\Delta U}{\Delta t},
$$

where $\dot{Q}_{i}^{+,-}$is the heat capacity (flow) delivered by the system (+) or released by system (-) flows (i); $\dot{W}_{n}^{+,-}$is transformation energy; $U$ is the system's internal energy; and $\Delta t$ is the time.

The expanded form of Eqn (1) is Eqn (2):

$$
\Sigma_{i}\left[\dot{Q}_{i}^{+}\right]+\Sigma_{j}\left[\dot{W}_{j}^{+}\right]=\Sigma_{i}\left[\dot{Q}_{i}^{-}\right]+\Sigma_{j}\left[\dot{W}_{j}^{-}\right]+\frac{\Delta U_{c z}}{\Delta t} .
$$

The sum of the numbers on the left side of the equation is the amount of incoming RE and it could be named as locally disposable renewable energy (LDRE):

$$
\Sigma_{i}\left[\dot{Q}_{i}^{+}\right]+\Sigma_{j}\left[\dot{W}_{j}^{+}\right]=L D R E .
$$

For assessment of renewable energy flows of building site authors offer to use RE flow characteristics. If they are included, the Eqn (3) could be rewritten as follows:

$$
\dot{Q}_{S}^{+}+\dot{Q}_{D G}^{+}+\dot{Q}_{S L}^{+}+\dot{M}_{A}^{+}\left[h_{A}+\frac{1}{2} C_{A}^{2}\right]=L D R E,
$$

where $\dot{Q}_{S}^{+}$- solar radiation heat; $\dot{Q}_{D G}^{+}$- heat coming from the underground; $\dot{Q}_{S L}^{+}$- heat flow of exchanging heat stream, occurring in the surface of soil (up to $10 \mathrm{~m}$ depth), W; $C_{A}-$ air flow speed, $\mathrm{m} / \mathrm{s} ; \dot{M}_{A}-$ mass flow rate of incoming air; $h_{A}$ - air enthalpy.

\subsection{Statistical indicators of RE flows}

Descriptive statistical analysis is used to evaluate the reliability of the energy supply. The statistical analysis sample is an hourly time step-year period covering parameters of the RE flow.

\section{Case study}

\subsection{Initial data}

Case study was performed to demonstrate the comprehensive evaluation of RES. The site of typical flat undeveloped area, near Vilnius city, in Lithuania was selected for the case study. The area has a slight roughness of terrain not planted with any greenery.

Independently chosen site is as an open steadily operating thermodynamic system. System volume $V$ is invariable. The system, limited only by theoretical limits, is surrounded by the atmosphere. Physical characteristics of chosen building site are presented in Table 1.

The calculations are carried out using the meteorological data (from METEONORM application) generated at the central site point. Data taken as average values reflecting the energy status of the whole site. It is understandable that the more detailed determination of the RE potential requires the dimensional computer simulation of flows, including the total volume and the influence of the

\begin{tabular}{|c|c|}
\hline Physical characteristic & Description \\
\hline Coordinates of the site & $54.792863,25.279806$ (WGS) \\
\hline $\begin{array}{l}\text { Area of the site (control } \\
\text { volume) }\end{array}$ & $100 \times 100 \mathrm{~m}(100 \times 100 \times 52 \mathrm{~m})$ \\
\hline $\begin{array}{l}\text { Vegetation within and } \\
\text { outside the site }\end{array}$ & $\begin{array}{l}- \text { Vegetation in the site }- \\
\text { grass/field } \\
- \text { Vegetation near the site }- \\
\text { grass/field }\end{array}$ \\
\hline Landscape characteristics & $1 \%$ over all slope to the NE side \\
\hline Albedo & Warm period -0.6 ; winter -0.8 \\
\hline Shadows & None \\
\hline $\begin{array}{l}\text { Ground layers characteris- } \\
\text { tics }\end{array}$ & $\begin{aligned}- & \text { Energy flow from deep } \\
& \text { ground layer - } \\
& 45.00 \mathrm{~mW} / \mathrm{m}^{2} \\
- & \text { Heat transfer coefficient } \\
& -1.5 \mathrm{~W} /\left(\mathrm{m}^{2} \mathrm{~K}\right)\end{aligned}$ \\
\hline
\end{tabular}
local barriers (vegetation, area roughness and so on) in this kind of site scale.

Table 1. Building site's physical characteristics

\subsection{Annual dynamics of the renewable energy flow potential}

The available energy dynamics of the selected area during the year is shown in Figure 4. Rounded numerical value of the air flow curve reflects the total available RE potential. 


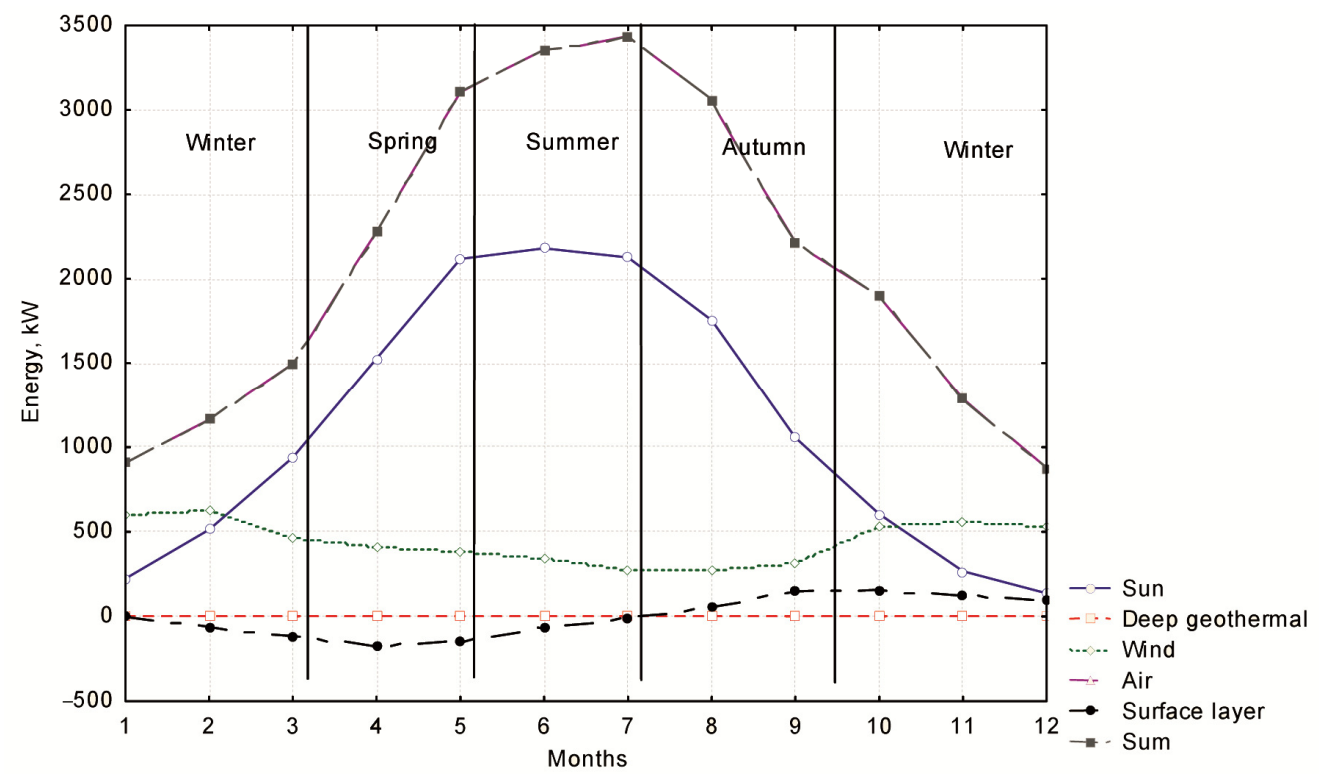

Fig. 6. Year preliminary division into seasons and overall dynamics of RE flows of selected building site

The diagram (Fig. 6) shows that the maximum energy potential $(3332 \mathrm{~kW})$ is in the summer. Meanwhile, the energy flow during the cold season is relatively small up to $30 \%$ of the maximum quantity of energy or about $881 \mathrm{~kW}$. The minimum positive value of solar energy is reached in winter time while air energy acquires the negative value, indicating the outgoing rather than ingoing energy. In autumn, the soil in $2 \mathrm{~m}$ depth starts to radiate the constantly accumulated heat. During the cold season, wind energy flow is a dominant RE flow in a site compared to the sun and soil energy.

It should be noted that both the soil and the wind energy flows are relatively stable over the year, without the exceptional deflection of energy amount, so seasonal accumulation phenomena must be judged only by assimilating solar and air energy flow.

Traditional determination of RE potential treats the air flow only as an energy carrier and excludes it from calculations. In order to assess overall RE potential of building's site in the same detail, the air flow should be considered as another RE source.

Depending on a climate zone there could be various profiles of the annual dynamics. Winter and summer periods are quite distinct in that case study. In addition to these target periods, there are the transition periods such as are spring and autumn (Fig. 6, vertical lines). Naturally, RE flow dynamics does not have clear transition points which could help to distinguish such periods. But various technologies have different efficiency in each period. Awareness of such periods provides additional information in planning hybrid RE systems. In this case study four periods could be excluded: cold period, the transition into the warm period, warm period and the transition into the cold period.

RE potential annual average value of the case study is $2051 \mathrm{~kW}$, i.e. average energy flow reaching the site or LDRE characteristic.

Assessment of the total dynamics of RE flows potential shows that it distinguishes oneself by chaotic change within the hour, day or month. Usually, average monthly or annual values of individual flows are used in solving the RE absorption tasks. Correct determination of the average flow value is crucial.

\subsection{Statistical assessment of the RE flows characteristics}

Statistical evaluation of the calculated data was performed by a computer program STATISTICA. The evaluation results show different characteristics dynamic of the individual RE flow. Figure 7 provides a monthly minimum, maximum and median flow power values. Lower and upper quartiles are shown separately.

As shown in the curve of statistical characteristics (Fig. 7), different RE flows have distinctive value changing dynamics. The solar energy reaches maximum in late spring, wind energy maximum is in winter, air and soil heat energy reaches its peak in the end of summer. Having this flow dynamics permits a more rational choice of the most acceptable source that would cover RE energy needs.

Average values of $25-75 \%$ range (quartile range $1495 \mathrm{~kW}$ ) are the most scattered ones in solar energy case, about $60 \%$ lower average values scatter in air and wind flows and minimum scatter $(200 \mathrm{~kW})$ is in soil heat flow case (Table 2). The scatters of those values characterize the permanency of the energy flow. Case study calculation shows that solar energy transformation system should operate in the widest range. When modelling a power transformer, it is reasonable to choose such transformation system so that the highest efficiency would be in the restricted range of quartile values. As it can be seen, in the case of the wind flow, there is a clear influence of single gusts. This is shown by clear passing mean and median values ( $433 \mathrm{~kW}$ mean and $230 \mathrm{~kW}$ median). When modelling the use of the wind flow this characteristic must be taken into account. Ground layer energy is the most stable energy flow because of high thermal inertia and temporary storage phenomena remains. 
Table 2. Summary of RE flows statistics

\begin{tabular}{lrrrrrrrr}
\hline \multicolumn{1}{c}{ Energy form/characteristics } & \multirow{2}{*}{ Mean } & \multirow{2}{*}{ Median } & Minimum & Maximum & $\begin{array}{c}\text { Lower } \\
\text { Quartile }\end{array}$ & $\begin{array}{c}\text { Upper } \\
\text { Quartile }\end{array}$ & $\begin{array}{c}\text { Quartile } \\
\text { Range }\end{array}$ & Std.Dev. \\
\hline Solar energy, kW & 1124 & 737 & 38 & 3523 & 332 & 1827 & 1495 & 941 \\
Wind, kW & 433 & 230 & 0 & 4939 & 75 & 554 & 479 & 590 \\
Air heat, kW & 494 & 403 & -683 & 2056 & 169 & 722 & 553 & 452 \\
Ground surface layer heat, kW & 6 & 5 & -331 & 316 & -94 & 106 & 200 & 126 \\
\hline Sum, kW & $\mathbf{2 0 5 7}$ & $\mathbf{1 8 0 1}$ & $\mathbf{1 3 2}$ & $\mathbf{6 8 7 9}$ & $\mathbf{9 7 1}$ & $\mathbf{2 9 2 4}$ & $\mathbf{1 9 5 3}$ & $\mathbf{1 3 3 1}$ \\
\hline
\end{tabular}
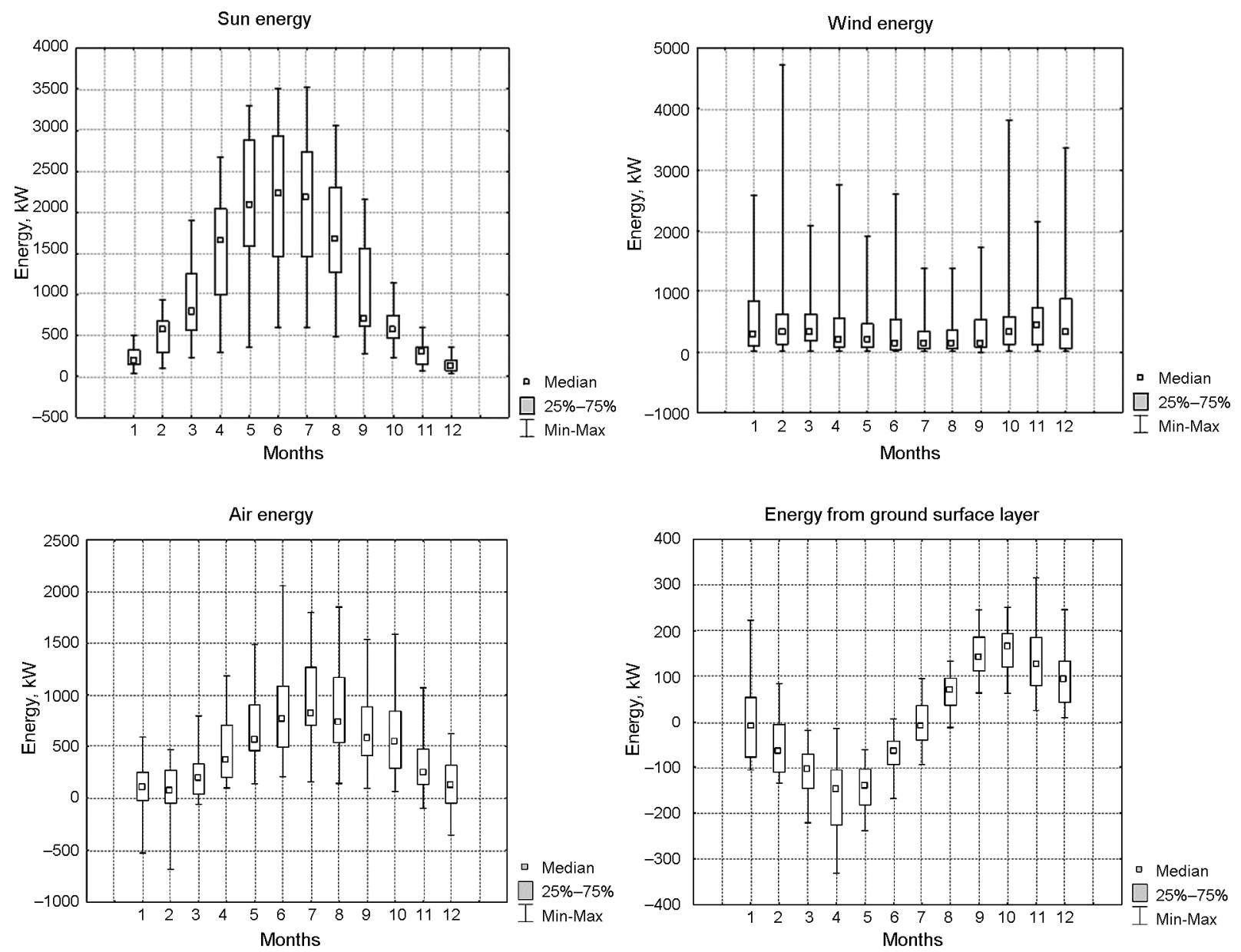

Fig. 7. Dynamic of RE energy flows (wind, solar, air heat and ground) statistics

The lower and upper quartiles in the solution phase allow dividing the energy flow into two parts: $0-50 \%$ values and $50-100 \%$ values. In this way, there are two medians: the median of the smaller power area $(0-50 \%)$ and the median of the major power area (50-100\%). Having those medians it is possible to make a more rational choice on the energy transformer which operates in a given season or throughout the year more efficiently.

The corresponding RE flow site reaching energy power weighted distribution in different seasons is presented in the Figure 8. Individual powers of the energy flow are divided into three ranges: minor powers - to the lower quartile values, middle-level powers - to quartile range values and major powers - to the flow values above the upper quartile. The main advantage of the graphs is that the information is presented in the form that allows understanding what is the power limit at which operating RE transformer would generate the biggest amount of energy and in which time of the year it could happen.

As it can be seen from the case study results, in the case of solar energy flow, up to $30 \%$ site reaching solar energy flow consists of the flow of energy in the summer, with the capacity reaching $1562 \mathrm{~kW}$ of the power level.

Wind energy reaches the site in major power range throughout the year, but considering the available statistical information presented earlier, wind energy is chaotic in a major value range and the main energy quantity is generated by individual extreme wind gusts. Solving a consistent supply of wind energy task it is appropriate choice for a small power range, which is only up to $10 \%$ of the total wind energy flow. 

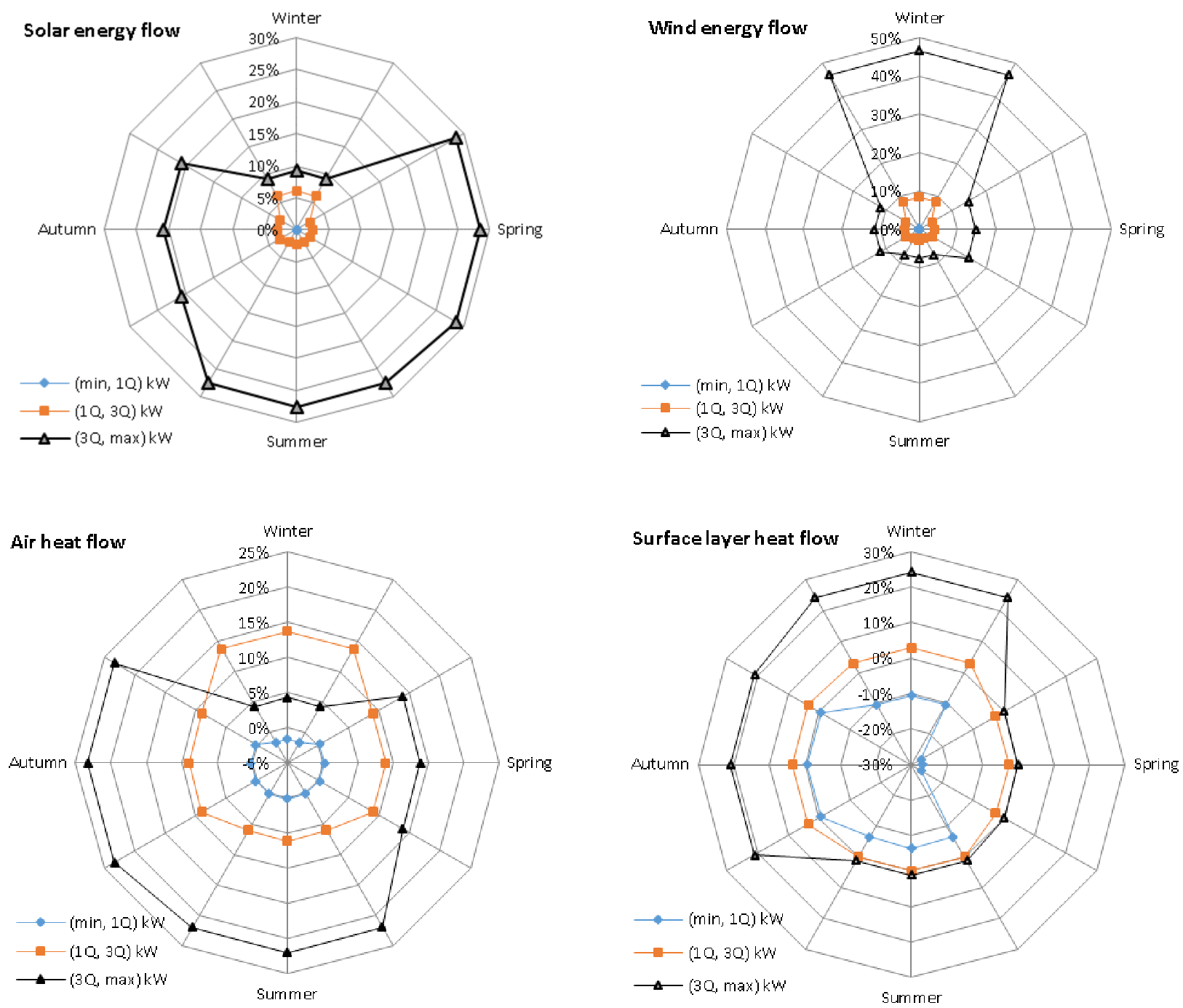

Fig. 8. Frequency of energy flow values throughout seasons.

Air flow energy reaching the site through the entire year is close to the medium, but like in the wind energy case, its part in the total energy flow is relatively small, which is up to $15 \%$ of the total air energy flow. Autumn in the air energy flow has its specifics, because in comparison with the spring, in autumn the flow of the energy reaching the site is greater (up to $23 \%$ ).

Soil heat energy flow calculation shows that the maximum benefit ( $25 \%$ from the total ground heat energy flow) comes in winter, when accumulated soil layer energy during the warm season begins to radiate into the cooling environment.

Having such a complex uniform level of RE flow information the base for the initial development of the site's energy concept is formed. Depending on the intended site's energy demand a RE source or it's combination can be chosen. For further modelling energy conversion technologies could be an option as well as the primary powers of system components or proportions of different solutions. Revising this preliminary concept and evaluating the usage of technological solutions, sites' technical $\mathrm{RE}$ potential should be determined in the next stage.

\section{Conclusions}

In authors opinion the evaluation of the RE reaching the building's site should be one of the main reference points for providing technical solutions when creating a building as new energy user. Taking into account the local conditions, the theoretical RE potential must be determined without being limited by different technological solutions and must have unlimited freedom for the engineering modelling of potential energy conversion options. The many the possible initial data with the same particularity have been taken into account, the more precisely RE potential was determined.

The proposed combined evaluation method of the $\mathrm{RE}$ amount is based on the energy balance of the site control volume. Evaluation model options and operation principle are presented in a case study of the locally available energy. The case study shows that the results of LDRE characteristics (annual average $2057 \mathrm{~kW}$ ) reveal the general energy state of the site. This helps to y compare the alternatives of the site directly. Also the calculations show that when determining the available RE potential, both the annual and the seasonal quantity change of 
flows has to be taken into account. Annual average of solar energy flow is $1124 \mathrm{~kW}$, while in summer time it reaches $30 \%$ of all solar energy, which average capacity is $1562 \mathrm{~kW}$. The case study confirms the assumption that the mathematical average of potential values is not sufficient for further modelling process. The individual values of extreme flows occurring in nature have to be eliminated. The case study shows that the greatest impact of extreme values is of wind energy flow. The annual average of flow is $433 \mathrm{~kW}$, while excluding the impact of extreme values, the average capacity is only $230 \mathrm{~kW}$. The transformer capacity selection should be based on the reoccurrence of the energy prevailing values. United statistical assessment of these values for different RE sources proposes additional useful information.

Assessment data doesn't reflect the final availability of energy yet; therefore the shift from a quantitative evaluation to the technology based evaluation is needed. The most sensitive in this approach is an air flow as energy transferring agent that contains a large amount of energy, which indicates the challenge for technologies. On the next step of research authors plan to assess technical potential of building site by analysing RES technologies and energy use profile.

\section{Nomenclature}

$\begin{array}{ll}\text { Subscripts } \\ S & \text { solar; } \\ D G & \text { deep geothermal; } \\ S L & \text { surface soil layer; } \\ A & \text { air. }\end{array}$

\section{Abbreviations}

AEC Architects, Engineers and Constructors;

RE Renewable energy;

IWDP Integrated Whole Building Design;

IPD Integrated Project Delivery;

ICT Information and Communication Technologies;

BIM Building Information Modelling;

GIS Geographic Information system;

LDRE Locally Disposable Renewable energy.

\section{Acknowledgements}

This work was supported by the Research Council of Lithuania under Grant No. ATE-03/2012.

\section{References}

Adeli, H. 2002. Sustainable infrastructure systems and environmentally-conscious design - a view for the next decade, Journal of Computing in Civil Engineering ASCE 16(4): 1-4. http://dx.doi.org/10.1061/(ASCE)08873801(2002)16:4(231)

Ali, M.; Armstrong, P. 2008. Overview of sustainable design factors in high-rise buildings, in Proc. of the CTBUH $8^{\text {th }}$ World Congress, 3-5 March 2008, Dubai, JAE, 282-291.

Altwies, J.; Nemet, G. F. 2013. Innovation in the U.S. building sector: an assessment of patent citations in building energy control technology, Energy Policy 52: 819-831. http://dx.doi.org/10.1016/j.enpol.2012.10.050
Angelis-Dimakis, A.; Biberacher, M.; Dominguez, J.; Fiorese, G.; Gadocha, S.; Gnansounou, E.; Guariso, G.; Kartalidis, A.; Panichelli, L.; Pinedo, I.; Robba, M. 2011. Methods and tools to evaluate the availability of renewable energy sources, Renewable and Sustainable Energy Reviews 15(2): 1182-1200.

http://dx.doi.org/10.1016/j.rser.2010.09.049

Azari-Najafabadi, R.; Ballard, G.; Cho, S.; Kim, Y.-W.2011. A dream of ideal project delivery system, in Proc. of The Architectural Engineering Conference (AEI) - Building Integrated Solutions, 30 March - 2 April 2011, Oakland, California, USA, 427-436. http://dx.doi.org/10.1061/41168(399)50

Barlish, K.; Sullivan, K. 2012. How to measure the benefits of BIM - A case study approach, Automation in Construction 24: 149-159. http://dx.doi.org/10.1016/j.autcon.2012.02.008

Beyene, A.; MacPhee, D.; Zevenhoven, R. 2012. Anthropogenic Heat and Exergy Balance of the Atmosphere, in Proc. of The $25^{\text {th }}$ International Conference on Efficiency, Cost, Optimization and Simulation of Energy Conversion Systems and Processes (ECOS), 26-29 June 2012, Perugia, Italy, 348-362.

Brauers, W. K. M.; Kracka, M; Zavadskas, E. K. 2012. Lithuanian case study of masonry buildings from the Soviet period, Journal of Civil Engineering and Management 18(3): 444-456. http://dx.doi.org/10.3846/13923730.2012.700944

Cholakis, P. N. 2011. 4D/5D BIM, JOC, IPD - Why the AEC industry must change, AACE International Transactions 2: 927-939.

Demirhan, H.; Menteş, T.; Atilla, M. 2013. Statistical comparison of global solar radiation estimation models over Turkey, Energy Conversion and Management 68: 141-148. http://dx.doi.org/10.1016/j.enconman.2013.01.004

Directive 2002/91/EC of the European Parliament and of the Council of 16 December 2002 on the energy performance of buildings, Official Journal, 04 January 2003, L001/0065-L001/0071.

Directive 2009/28/EC of the European Parliament and of the Council of 23 April 2009 on the promotion of the use of energy from renewable sources and amending and subsequently repealing Directives 2001/77/EC and 2003/30/EC, Official Journal of the European Union, 5 June 2009, L140/16-L140/47.

Directive 2010/31/EU of the European Parliament and of the Council of 19 May 2010 on the energy performance of buildings (EPBD), Official Journal of The European Union, 18 June 2010, L153/13-L153/35.

Džiugaitè-Tumènienė, R.; Jankauskas, V; Motuzienė, V. 2012. Energy balance of a low energy house, Journal of Civil Engineering and Management 18(3): 369-377. http://dx.doi.org/10.3846/13923730.2012.691107

Hermann, W. A. 2006. Quantifying global exergy resources, Energy 31(12): 1685-1702. http://dx.doi.org/10.1016/j.energy.2005.09.006

Jorgensen, S. E.; Svirezhev, Y. M. 2004. Towards a thermodynamic theory for ecological systems. Elsevier Ltd. 380 p.

Kaczorek, D; Koczyk, H. 2013. Structural solutions impact on thermal energy efficiency of heating surface at an open space, Journal of Civil Engineering and Management 19(6): 883-893. http://dx.doi.org/10.3846/13923730.2013.840333 
Lapinskienè, V.; Martinaitis, V. 2013. The framework of an optimization model for building envelope, Procedia Engineering 57: 670-677. http://dx.doi.org/10.1016/j.proeng.2013.04.085

Lapinskiene, V.; Motuziene, V.; Martinaitis, V. 2014. Multiobjective optimization of shading solutions for a standard family house under Lithuanian conditions, in Proc. of the $9^{\text {th }}$ International Conference "Environmental Engineering”, 22-23 May 2014, Vilnius, Lithuania, 1-7.

Liao, W.; Heijungs, R.; Huppes, G. 2012. Thermodynamic analysis of human-environment systems: a review focused on industrial ecology, Ecological Modelling 228: 76-88. http://dx.doi.org/10.1016/j.ecolmodel.2012.01.004

Lin, Y.-C. 2014. Construction 3D BIM-based knowledge management system: a case study, Journal of Civil Engineering and Management 20(2): 186-200. http://dx.doi.org/10.3846/13923730.2013.801887

Malczewski, J. 2006. Ordered weighted averaging with fuzzy quantifiers: GIS-based multicriteria evaluation for landuse suitability analysis, International Journal of Applied Earth Observation and Geoinformation 8: 270-277. http://dx.doi.org/10.1016/j.jag.2006.01.003

Meteotest. 2013. Meteonorm version 7.0.20 - handbook [online], [cited 10 October 2013]. Available from Internet: www.meteonorm.com

Migilinskas, D.; Popov, V.; Juocevičius, V.; Ustinovičius, L. 2013. The benefits, obstacles and problems of practical BIM implementation, Procedia Engineering 57: 767-774. http://dx.doi.org/10.1016/j.proeng.2013.04.097

Mikučionienė, R.; Martinaitis, V.; Keras, E. 2014. Evaluation of energy efficiency measures sustainability by decision tree method, Energy and Buildings 76: 64-71. http://dx.doi.org/10.1016/j.enbuild.2014.02.048

Ministry for the Environment Wellington. 2008. Integrated whole building design guidelines [online], [cited 01 February 2014]. Available from Internet:

http://www.mfe.govt.nz/publications/sus-dev/integratedwhole-building-design-guidelines/integrated-buildingguidelines.pdf

Monstvilas, E.; Stankevičius, V.; Karbauskaite, J.; Burlingis, A.; Banionis, K. 2012. Hourly calculation method of building energy demand for space heating and cooling based on steady-state heat balance equations, Journal of Civil Engineering and Management 18(3): 356-368. http://dx.doi.org/10.3846/13923730.2012.689994

Motuzienè, V.; Bielskus, J. 2014. Assessment of overall performance of building integrated photovoltaics, in Proc. of the $9^{\text {th }}$ International Conference "Environmental Engineering”, 22-23 May 2014, Vilnius, Lithuania, 1-9.

Motuziené, V.; Vilutiene, T. 2013. Modelling the effect of the domestic occupancy profiles on predicted energy demand of the energy efficient house, Procedia Engineering 57: 798-807. http://dx.doi.org/10.1016/j.proeng.2013.04.101

Motuzienė, V.; Vilutienė, T.; Rogoža, A. 2013. Environmental performance of energy efficient residential building - a case study of Lithuania, in Proc. of the Sustainable Buildings - Construction Products and Technologies (CB13), 25-28 September 2013, Graz, Austria, 351-358.

Muratori, M.; Roberts, M. C.; Sioshansi, R.; Marano, V.; Rizzoni, G. 2013. A highly resolved modelling technique to simulate residential power demand, Applied Energy 107: 465-473.

http://dx.doi.org/10.1016/j.apenergy.2013.02.057

Omitaomu, O. A.; Blevins, B. R.; Jochem, W. C.; Mays, G. T.; Belles, R.; Hadley, S. W.; Harrison, T. J.; Bhaduri, B. L.; Neish, B. S.; Rose, A. N. 2012. Adapting a GIS-based multicriteria decision analysis approach for evaluating new power generating sites, Applied Energy 96: 292-301. http://dx.doi.org/10.1016/j.apenergy.2011.11.087

Ondreka, J.; Rusgen, M. I.; Stober, I.; Czurda, K. 2007. GISsupported mapping of shallow geothermal potential of representative areas in south-western Germany Possibilities and limitations, Renewable Energy 32(13): 2186-2200. http://dx.doi.org/10.1016/j.renene.2006.11.009

Parasonis, J.; Keizikas, A.; Endriukaityte, A.; Kalibatienė, D. 2012. Architectural solutions to increase the energy efficiency of buildings, Journal of Civil Engineering and Management 18(1): 71-80.

http://dx.doi.org/10.3846/13923730.2011.652983

Popov, V.; Juocevičius, V.; Migilinskas, D.; Ustinovičius, L.; Mikalauskas, S. 2010. The use of a virtual building design and construction model for developing an effective project concept in 5D environment, Automation in Construction 19(3): 357-367. http://dx.doi.org/10.1016/j.autcon.2009.12.005

QcustomPlot. 2013. [online], [cited 11 November 2013]. Available from Internet:

http://www.qcustomplot.com/index.php/introduction.

Sebastian, R. 2010. Integrated design and engineering using building information modelling: a pilot project of smallscale housing development in The Netherlands, Architectural Engineering and Design Management 6(2): 103110. http://dx.doi.org/10.3763/aedm.2010.0116

Shukuya, M.; Komuro, D. 1996. Exergy-Entropy process of passive solar heating and global environmental systems, Solar Energy 58(1-3): 25-32. http://dx.doi.org/10.1016/0038-092X(96)00064-3

Sorrentino, G.; Scaccianoce, G.; Morale, M.; Franzitta, V. 2012. The importance of reliable climatic data in the energy evaluation, Energy 48(1): 74-79. http://dx.doi.org/10.1016/j.energy.2012.04.015

The American Institute of Architects (AIA). 2013. Integrated project delivery: A guide (Version 1) [online], [cited 03 February 2014]. Available from Internet: http://info.aia.org/siteobjects/files/ipd_guide_2007.pdf

Umit, I. 2012. Design patterns for BIM-based service-oriented architectures, Automation in Construction 25: 59-71. http://dx.doi.org/10.1016/j.autcon.2012.04.013

Valero, A.; Valero, A.; Martinez, A. 2010. Inventory of exergy resources on earth including its mineral capital, Energy 35(2): 989-995. http://dx.doi.org/10.1016/j.energy.2009.06.036

Van Hoesen, J.; Letendre, S. 2010. Evaluating potential renewable energy resources in Poultney, Vermont: A GISbased approach to supporting rural community energy planning, Renewable Energy 35(7): 2114-2122. http://dx.doi.org/10.1016/j.renene.2010.01.018

Volk, R.; Stengel, J.; Schultmann, F. 2014. Building Information Modeling (BIM) for existing buildings - Literature review and future needs, Automation in Construction 38: 109-127. http://dx.doi.org/10.1016/j.autcon.2013.10.023

Wall, G.; Gong, M. 2001. On exergy and sustainable development - Part 1 Conditions and concepts, Exergy, An International Journal 1(3): 128-145. http://dx.doi.org/10.1016/S1164-0235(01)00020-6

Wang, N.; Adeli, H. 2013. Sustainable building design, Journal of Civil Engineering and Management 20(1): 1-10. http://dx.doi.org/10.3846/13923730.2013.871330

Watson, A. 2011. Digital buildings - Challenges and opportunities, Advanced Engineering Informatics 25(4): 573-581. http://dx.doi.org/10.1016/j.aei.2011.07.003 
Wright, J.; Charalambides, J. 2011. Building information modeling and integrated project delivery: What is the future?, in Proc. of Annual Conference - Canadian Society for Civil Engineering, 14-17 June 2011, Ottawa, Ontario, 2629-2638.

Xie, H.; Tramel, J. M.; Shi, W. 2011. Building information modeling and simulation for the mechanical, electrical, and plumbing systems, in Proc. of the IEEE, International Conference on Computer Sciece and Automation Engineering (CSAE), 10-12 June 2011, Shanghai, China, vol. 3, 77-80.

http://dx.doi.org/10.1109/CSAE.2011.5952637
Žèkas, V.; Martinaitis, V.; Šiupšinskas, G. 2013. Data file of the building site's renewable energy characteristics, in Proc. of the International Congress on Energy Efficiency and Energy Related Materials (ENEFM'2013), 9-12 October 2013, Antalya, Turkey, Springer Proceedings in Physics 155: 405-410.

http://dx.doi.org/10.1007/978-3-319-05521-3_52

Vygantas ŽĖKAS. PhD student, junior researcher at Dept. of Building Energetics of Vilnius Gediminas Technical University. Masters' degrees in Industry Engineering (2005) and Energy Engineering (2009). Author and co-author of 6 scientific publications. Research interests: energy use and supply systems for indoor climate of sustainable housing; renewable energy resources and building audit.

Vytautas MARTINAITIS. Professor, Head of Building Energetics Dept. of Vilnius Gediminas Technical University. Doctor Habil of Sciences (Energy and Thermal Engineering), 2000. Doctor of Technical sciences, 1982. Author and coauthor of more than 110 scientific and technical publications. Research interests: energy use and supply systems for indoor climate of sustainable housing; thermodynamic, exergy and life cycle analysis; energy planning and demand side management; energy audit and renovation.

Giedrė STRECKIENĖ. Dr Assoc. Prof. at Dept. of Building Energetics of Vilnius Gediminas Technical University. Doctor of Technological Sciences (Energy and Thermal Engineering), 2011. Publications: author and co-author of 20 scientific publications. Research interests: cogeneration and thermal energy storage technologies; numerical simulation of thermal processes.

Tatjana VILUTIENE. Dr Assoc. Prof. at Department of Construction Technology and Management, Vilnius Gediminas Technical University. Doctor of Technological Sciences (civil engineering), 2004. Publications: author and co-author of 2 text books and 47 scientific publications. Research interests: construction technology and management, decision-making, energy efficiency, renovation. 